\title{
LEITURAS
}

$\mathrm{DE}$

\section{ANTONIO CANDIDO}

\author{
Homenagem ao centenário de nascimento \\ de Antonio Candido
}

(1918-2017)

\section{Organização}

Manoel Freire

Marcos Falchero Falleiros

Rosanne Bezerra de Araújo 
Sumário

- Apresentação - Leitores de Antonio Candido.

Marcos Falchero Falleiros

- Algumas memórias segundo Antonio Candido.

Afonso Henrique Fávero

- Antonio Candido: a dialética entre o local e o universal.

Candice Carvalho

- Notas para um verbete do Vocabulário Antonio Candido.

Francisco Roberto Papaterra Limongi Mariutti

- Ecos de um passado emudecido: uma leitura do poema Memórias das águas, de Diógenes da Cunha Lima.

Gabriella Kelmer; Derivaldo dos Santos

- Dialética da ordem e da desordem: uma leitura de "Malagueta, Perus e

Bacanaço".

Manoel Freire

- Antonio Candido e o elogio da literatura.

Marcos Falchero Falleiros

- Antonio Candido, leitor do Fausto.

Marcus Vinicius Mazzari

- O crítico e o cronista na interface de um gênero "menor".

Maria de Lourdes Patrini Charlon; Mácio Alves de Medeiros

- Sob a égide da revolta - o Conde de Monte Cristo e a crítica de Antonio Candido. Mona Lisa Bezerra Teixeira

- A poética hiper-regional do "sertão" de Rosa no “chão" de Saramago.

Peterson Martins Alves Araújo

- Reflexão sobre a cultura brasileira e o efeito do influxo externo.

Rosanne Bezerra de Araújo; Jorge Witt de Mendonça Junior 


\title{
APRESENTAÇÃO - LEITORES DE ANTONIO CANDIDO PRESENTATION - READERS OF ANTONIO CANDIDO
}

\author{
Marcos Falchero Falleiros ${ }^{1}$ \\ Universidade Federal do Rio Grande do Norte
}

\section{RESUMO}

A obra de Antonio Candido representou de modo abrangente uma interpretação da cultura brasileira sob a forma de um discurso caseiro, no tom familiar, pleno de humor, de uma conversa entre amigos. A linguagem límpida de sua obra crítica deu ao Brasil mapa, régua e compasso. Uma coerência assombrosa percorreu, com a longevidade de mais de setenta anos, sua atuação intelectual e política, fundada em aspectos complexos que o autor traduziu para o senso comum, como, por exemplo, a obviedade da relação entre literatura, como texto, produto estético, e a realidade, como contexto da exterioridade histórica que a forma literária interioriza. Os ensaios reunidos nessa coletânea pretendem demonstrar o aprendizado modesto de discípulos de terceira geração e manter viva, no deserto de um tempo sombrio, a chama de humanismo e gentileza do querido mestre.

PALAVRAS-CHAVE: Antonio Candido; Cultura brasileira; Humor e malandragem; Humanismo e gentileza.

\begin{abstract}
The work of Antonio Candido represented, broadly, an interpretation of Brazilian culture in the form of a homemade discourse, in the familiar tone, full of humor, in a conversational style. The clear language of his criticism gave to Brazil a map, a ruler and a compass. A striking coherence, supported by a longevity of more than seventy years, covered his intellectual and political intervention, based on complex aspects that the author translated into common sense, such as the truism of the relationship between literature, as a text, as an aesthetic product, and reality as the context of the historical world that the literary form shapes. The essays gathered in this collection are intended to demonstrate the modest learning of the third generation of Candido's disciples as an attempt to keep alive, in the desolate landscape of dark times, the flame of humanism and kindness that we inherited from our dearest master.
\end{abstract}

KEYWORDS: Antonio Candido; Brazilian culture; Humor and trickery; Humanism and kindness.

\begin{abstract}
Para mim, o mundo do Vovô Candido - como todas as seis netas e o único neto homem o chamam - é tecido nas linhas da memória e do afeto. Começa quando o primeiro antepassado pisa em terras brasileiras e nunca termina de ser costurado. Parte do princípio de que somos todos personagens de uma mesma história, ligados por existências múltiplas e cheias de significado, não importando se fomos barbeiros na sua pequena Santa Rita de Cássia, escravos libertos de uma fazenda esquecida do sul de Minas, influentes barões de Cerro Azul, comerciantes poliglotas ou fazendeiros de café que sonham em ser poetas. Cada um dos milhares de filhos das suas árvores
\end{abstract}

\footnotetext{
${ }^{1}$ Doutor em Literatura Brasileira pela Universidade de São Paulo. Professor de Literatura Brasileira e Literatura Comparada da Universidade Federal do Rio Grande do Norte - UFRN. E-mail: marcffal@gmail.com
} 


\author{
genealógicas favoritas (colecionadas ao longo de quase um século) tem uma história e \\ uma marca para ser lembrada.
}

Maria Clara Vergueiro, O mundo de meu avô era o meu preferido.

\title{
A preposição de
}

O título que enlaça os participantes desta coletânea, Leituras de Antonio Candido, padece da ambiguidade típica da preposição de, irresoluta entre a significação de agente e a de objeto: pois não se sabe, de saída, se o que pretendemos apresentar são leituras que Antonio Candido realizou ao longo de sua vida intelectual ou se queremos pretensiosamente anunciar nossa absorção de migalhas, quiçá proveitosa, da interpretação fundadora da história da cultura brasileira, que através de suas obras o crítico nos legou.

Trata-se, entretanto, de uma duplicidade auspiciosa, que condensa no mesmo gesto prepositivo a dialética agente-paciente entre o mestre erudito, leitor penetrante do mundo, e os discípulos, seus leitores, a quem o pedagogo entrega para decifração reflexiva os seus desvelamentos, além de nos fornecer mapa, régua e compasso.

Há também na designação que escolhemos a coincidência lisonjeira do mesmo tipo de ambiguidade que se encontra numa obra tão cara a Antonio Candido quanto devedora do prestígio potencializado às alturas pelo crítico: Memórias de um sargento de milícias - um título cuja formulação só se esclarece à medida que a narrativa revela que as aventuras de Leonardo não são as suas memórias, contadas por ele, que todas as suas malandragens são pregressas e acabam justamente no momento em que o traquinas se arranja na função de sargento de milícias. São casos relatados pelo ouvir-dizer de um narrador bonachão inominado e as "memórias", portanto, não são proferidas pelo sargento, mas compleição de uma obra que só teve o tamanho de sua força expressiva devidamente reconhecido quando o Mestre-Açu- $\mathrm{AC}^{3}$ nos brindou com o grande modelo brasileiro e universal de crítica literária, que desvelou seu sentido mais profundo: o ensaio "Dialética da malandragem".

\section{Sincronia e diacronia}

As animadas peripécias de Memórias de um sargento de milícias (1991) permitiram com a proposição interpretativa desse ensaio, em 1970, uma condensação de resultados. Para o período mais sinistro da ditadura militar, no calor da hora, significou, como um gesto de resistência, um aceno de esperança com a dose de alegria de um mundo sem culpa, em allegro vivace, sob a divisa de ópera bufa do "Tutto nel mondo è burla" (CANDIDO, 1970, p. 80), quem sabe se não inspirado pelas conjecturas benevolentes de outros tempos, vindas da obra querida do querido amigo, Sérgio Buarque de Holanda ${ }^{4}$, em Raízes do Brasil. No início:

\footnotetext{
${ }^{2}$ Entretanto, a preposição em questão, a primeira do título, "memórias de", ganha coerência extratextualmente se tivermos em conta a possível fonte da narrativa, o "sargento" citado nessa passagem de Antonio Candido ao situar Leonardo como um malandro "que Manuel Antônio com certeza plasmou espontaneamente, ao aderir com a inteligência e a afetividade ao tom popular das histórias que, segundo a tradição, ouviu de um companheiro de jornal, antigo sargento comandado pelo major Vidigal de verdade" (CANDIDO, 1998, p. 25-26).

3 Entre muitos de nós, estudantes de letras, "Mestre-açu Acê" tornou-se o apelido carinhoso dado a Antonio Candido a partir da formulação bem-humorada que Roberto Schwarz registrou na dedicatória de uma de suas primeiras coletâneas de ensaios, O pai de família e outros estudos (SCHWARZ, 1978).

${ }^{4}$ Em suas memórias, Ana Luisa Escorel (2008), filha de Antonio Candido, fala dessa amizade: "Um dia, o amigo veio visitar e chegou perguntando se o pai queria a máquina dele. A mulher, que também tinha vindo, reagiu no ato, indignada [...]. O marido tinha comprado uma máquina nova e estava querendo empurrar a velha [...]. Embora agradecido com a atenção da amiga, em geral severa com o marido, mais para atarantado frente aos aspectos práticos
} 
Hoje, a simples obediência como princípio de disciplina parece uma fórmula caduca e impraticável e dá, sobretudo, a instabilidade constante de nossa vida social. Desaparecida a possibilidade desse freio, é em vão que temos procurado importar dos sistemas de outros povos modernos, ou criar por conta própria, um sucedâneo adequado, capaz de superar os efeitos de nosso natural inquieto e desordenado. (HOLANDA, 2016, p. 55).

E no fim:

Poderemos ensaiar a organização de nossa desordem segundo esquemas sábios e de virtude provada, mas há de restar um mundo de essências mais íntimas que, esse, permanecerá sempre intato, irredutível e desdenhoso das invenções humanas. Querer ignorar esse mundo será renunciar ao nosso próprio ritmo espontâneo, a lei do fluxo e do refluxo, por um compasso mecânico e uma harmonia falsa. (HOLANDA, 2016, p. 331).

Com afirmar que aquele romance-de-fadas publicado entre 1854-1855 era conduzido pelo espírito do "Tutto nel mondo è burla", o crítico matava dois coelhos com uma só cajadada: pois se o ensaio respondia com o aceno da irreverência ao tempo sombrio específico naquele momento das estações repressivas da história brasileira, a triste parada do golpe militar de 1964, sua metodologia rebatia concretamente os efeitos que calhavam como luva para os dedos da época: a pasteurização estruturalista que nos embutia no texto pelo texto para evitar nas abordagens da crítica estética o assunto inconveniente da realidade que a literatura absorve em sua forma.

O equacionamento do ensaio dava curso à coerência que acompanhou o longo percurso intelectual de Antonio Candido, permeado de fases que não se configuravam como correção de rumos ou recuos, mas sim aprofundamento das mesmas posições de saída. O crítico, portanto, retomava, de fato, o capítulo de Formação da literatura brasileira, que ali figurava sob o título "Manuel Antônio de Almeida: o romance em moto contínuo" (1971, p. 215-220, v. 2), dentro do capítulo geral "O triunfo do romance".

Não é preciso repetir em detalhes o quanto essa primeira leitura estava situada num corpo de análise geral, isto é, a obra fundamental do autor sobre os momentos decisivos da formação da literatura brasileira, em que literatura e contexto histórico se entrelaçavam dentro dos mesmos pressupostos que, em ponto pequeno, viriam a ser aprofundados em "Dialética da malandragem". Assim, aspectos que seriam reelaborados em 1970 apresentam seus embriões naquele capítulo, cuja superficialidade, diluída na profunda conexão de um contexto amplificado, dá indícios de percepções que levariam posteriormente à complexidade e ao refinamento interpretativos que o ensaio pontualmente alcançou.

A qualificação de "romance picaresco", que em 1970 seria o leitmotiv em negativo da releitura e constestação dessa categoria, então substituída pela revelação do "romance malandro" como "romance representativo", aparece em Formação mais inocentemente ao lado da obra, mas ainda assim posta em paralelo, sem qualificar explicitamente Memórias de um sargento de milícias como tal. Embora apresentando Manuel Antônio de Almeida como um "romancista de costumes", voltado para a "visão direta da sociedade" - uma caracterização que seria radicalmente revirada - o crítico já destacava a capacidade do romancista de "estrangular a

da existência, virando-se para ele, o pai da menina perguntou: - Foi nela que você escreveu Raízes do Brasil? No que a resposta veio que sim, decidiu, firme: - Então, eu quero. Buscou a máquina, mandou reformar e trabalhou nela anos a fio tirando das teclas redondas, espaçosas - letra branca sobre fundo preto - o resultado de que foi capaz. [...] Nessa Royal o pai produziu bastante. Grande parte de uma reflexão extensa sobre literatura brasileira que não acabava nunca: começou algum tempo depois de a menina nascer, por volta de 1945, e terminou quando ela já era quase uma mocinha de 13 anos". 
retórica embriagadora, a distorção psicológica, o culto do sensacional” (1971, p. 219-220, v. 2). E um aspecto da obra que daria ao ensaio um ponto de análise fundamental para a totalidade de seu sentido, já vinha ali demarcado no capítulo breve de Formação: "a surpreendente imparcialidade com que trata os personagens, rompendo a tensão romântica entre o Bem e o Mal por meio de um nivelamento divertido dos atos e caracteres" (CANDIDO, 1971, p. 215, v. 2). Além do "moto contínuo" do título, que evoluiria para a "dialética da ordem e da desordem", o allegre vivace do "Tutto nel mondo è burla", aparecia como "sarabanda":

Depois das traquinagens, dos padres bilontras, dos feiticeiros, das festas religiosas, das 'súcias' e das visitas, nada mais lhe restava: tinha sido moleque, coroinha, serviçal do Rei, soldado. Que lhe restava, de fato? A "felicidade cinzenta e neutra" de que fala Mário de Andrade, acentuando que o "livro acaba quando o inútil da felicidade principia".

Com efeito, a felicidade é estática por vocação, e a lei principal das Memórias é o movimento. A impressão que nos deixa é de sarabanda - bizarra e alegre sarabanda em que os grupos vão e vêm, os pares se unem e separam, as combinações são por vezes estranhas, mas nada é irremediável. (CANDIDO, 1971, p. 217, v. 2).

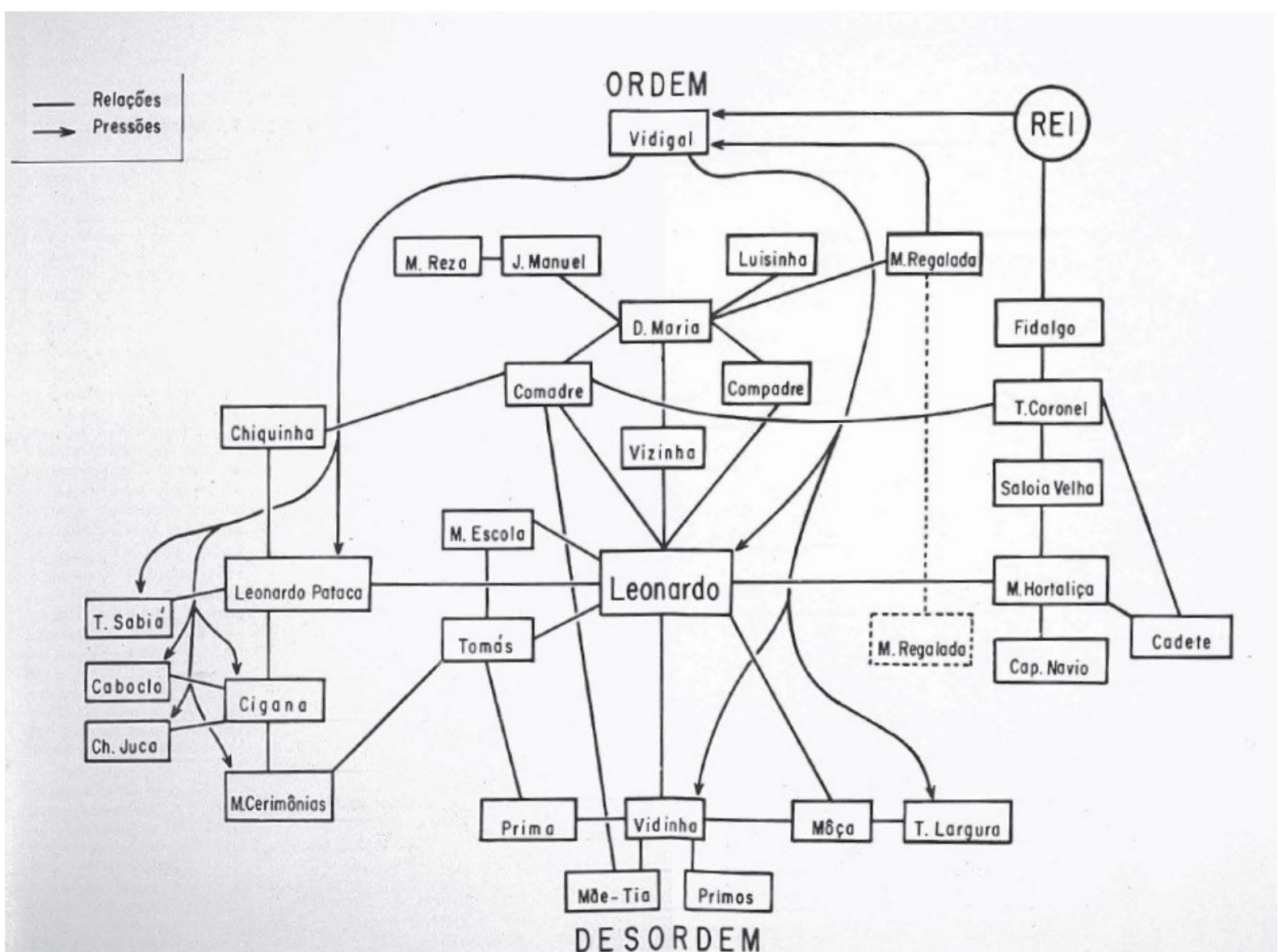

Fig. 1 - O diagrama à moda estruturalista: somente na 1a. edição de "Dialética da malandragem". 5 ${ }^{5}$ Curiosamente, o autor equivocou-se, na $1^{\mathrm{a}}$. edição, de 1970 , com a citação de um personagem de Memórias de um
sargento de milícias: "Teotônio", que é indicado no texto daquela publicação como "Teotoninho Sabiá" e assim
também foi referido como aparece acima, abreviadamente, no gráfico. Nas edições sucessivas, além da supressão do
gráfico, as menções do nome no texto foram corrigidas. Mais que lapso de sua lendária memória prodigiosa, o
engano sugere a retentiva mnemônica sensibilizada pela figuração marcante de Graciliano Ramos (1984, p. 60) em 
Fonte: R evista do IEB, n. 8, $1970 .{ }^{6}$

Depois, sob a atmosfera de opressão e censura, o crítico apresentou seu ensaio estrategicamente - com a sabedoria popular da astúcia, "a coragem do pobre" - para lembrar seja o ditado nordestino sempre referido ao picaresco dos personagens de Ariano Suassuna (VILAÇA, 1990), seja a menção de Benjamin quando caracteriza o narrador oral na figura do justo com as polaridades de efeito do conto de fadas, sendo uma delas aquela que dialetiza a coragem (Mut) através da astúcia (Untermut) (BENJAMIN, 1985, p. 215). Assim, um humor pince-sans-rire fingia-se aderente à metodologia impositiva da temporada estruturalista para subvertê-la, incorporando a malandragem de seu tema no próprio movimento da divulgação a público do ensaio.

Não bastasse tanta condensação de significações, "Dialética da malandragem" revelava-se o modelo metodológico número um para a crítica literária made in Brąil, mas de importância universal. O crítico desvendava uma forma que não era a do "romance picaresco", mas o representativo "romance malandro": anunciava, mais nitidamente que nos trabalhos anteriores, uma forma brasileira, e nisto, a historicidade da estrutura, no sentido, sob viés materialista, do que Lukács em A teoria do romance (2000) qualificou como "condicionamento histórico-filosófico" das formas literárias. Como lembrou Roberto Schwarz, em "Pressupostos, salvo engano, de 'Dialética da malandragem"”:

\footnotetext{
Quanto ao estruturalismo, a maneira exaustiva de levantar os passos da intriga, apoiada até num bonito gráfico, é talvez uma homenagem de Antonio Candido às suas exigências, que por esta via são incorporadas produtivamente. No que diz respeito à forma, entretanto, que é o essencial, as posições são diferentes. Como vimos, em "Dialética da Malandragem" a noção de forma está referida à prática histórica. A oposição de ordem e desordem não faz parte de um quadro universalista; pelo contrário, ela é esclarecida à luz do movimento e do momento sociais, onde os termos encontram a sua dialética. (SCHWARZ, 1987, p. 147-148).
}

Posteriormente, na publicação definitiva em livro, em O discurso e a cidade (CANDIDO, 1998, p. 45), o "bonito gráfico" referido por Schwarz foi suprimido. O autor manteve da publicação original somente um dos gráficos, o de menor proporção que ali figurava para explicar seu conceito de "redução estrutural", concernente à relação entre os dados particulares do real e o mundo fictício.

É esta redução estrutural que absorve a significação daqueles dados, projetando-os na construção do texto literário, não porque represente descritivamente, como um documentário, a história do tempo (da qual, como observa o crítico, o romance excluiu a base fundamental daquela sociedade: os escravos), mas porque apreende o seu "ritmo".

Em termos simplificados, poderíamos entender que o escritor ao captar e interpretar o "ritmo", ou - diríamos com imprecisão - o espirito do lugar e da bistória, e transformar essa percepção da ampla exterioridade do real em operações de construção interna do texto literário, isto é, em registro formal no reino da linguagem, terá como resultado uma obra esteticamente relevante, independentemente de esse resultado ser, por exemplo, a argentinidade europeia de Jorge Luis Borges representando estórias das arábias ou Manuel Antônio de Almeida retomando o "tempo do rei" no Rio de Janeiro de décadas anteriores ao seu tempo. É nesse sentido que a literatura interpreta, representa, esclarece e desvenda o real:

Infância, ao descrever um vizinho de Buíque, cujas pernas finas lhe granjearam o apelido: "Teotoninho Sabiá piscava os olhos amarelos de ave, sacudia as grandes asas depenadas e bocejava um cacarejo inexpressivo".

${ }^{6}$ A forma mais acessível de consulta à Revista do Instituto de Estudos Brasileiros, IEB-USP, n. 8, 1970, é pela internet, com a reprodução do original, onde o gráfico se encontra entre as páginas $78-79$, em: < revistas.usp.br/rieb/article/ view/69638 >. Acesso em 06 jan. 2013. 
Com efeito, não é a representação dos dados concretos particulares que produz na ficção o senso da realidade; mas sim a sugestão de uma certa generalidade, que olha para os dois lados e dá consistência tanto aos dados particulares do real quanto aos dados particulares do mundo fictício. No esquema abaixo, sejam OD o fenômeno geral da ordem e da desordem, como foi indicado; $A B$ os fatos particulares quaisquer da sociedade joanina do Rio; A'B' os fatos particulares quaisquer da sociedade descrita nas Memórias:

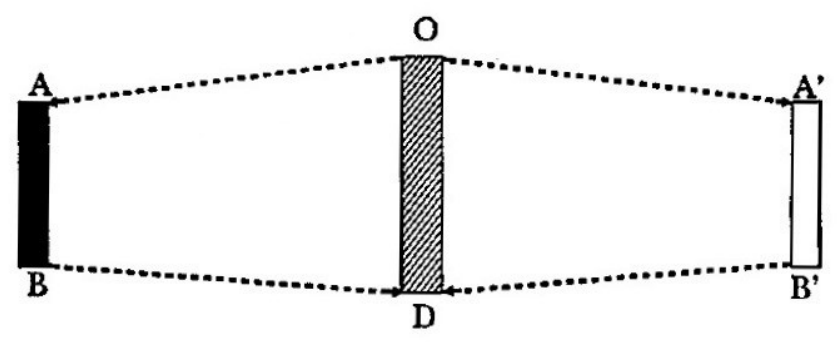

OD, dialética da ordem e da desordem, é um princípio válido de generalização, que organiza em profundidade tanto $\mathrm{AB}$ quanto $\mathrm{A}^{\prime} \mathrm{B}^{\prime}$, dando-lhes inteligibilidade, sendo ao mesmo tempo real e fictício -, dimensão comum onde ambos se encontram, e que explica tanto um quanto outro. A'B' não vem diretamente de $\mathrm{AB}$, pois o sentimento da realidade na ficção pressupõe o dado real mas não depende dele. Depende de princípios mediadores, geralmente ocultos, que estruturam a obra e graças aos quais se tornam coerentes as duas séries, a real e a fictícia. (CANDIDO, 1998, p. 45-46).

A tal processo de refinada leitura certamente Roberto Schwarz (1990) deu curso na percepção e elaboração crítica, em Memórias póstumas de Brás Cubas, do narrador volível, elemento materialmente literário da apreensão e projeção no construto estético de uma elite escravagista e irresponsável no Brasil do século XIX. É dentro dessa concepção que ele esclarece o assunto do esquema acima descrito por Candido: "não se trata de um realismo espelhista, pois uma forma não é toda a realidade, além do que ela pode se combinar com elementos historicamente incaracterísticos (o aspecto folclórico das Memórias [de um sargento de milícias], que leva o romance para o lado do fabuloso)" (SCHWARZ, 1987, p. 141).

Pode-se objetar que "Dialética da malandragem" afirma mais claramente uma convivência harmônica ou concessiva entre a ordem e a desordem do que propriamente uma dialética acirrada, entre tese e antítese, na representação literária de sua dinâmica real no "tempo do rei". Destaque-se, contudo, no plano da abordagem crítica de sua leitura, a eficiência do método na operação dialética entre forma literária e processo social, que apreende a síntese do "modo de ser brasileiro", ainda que esta possa ser uma categoria problemática, como vê Roberto Schwarz. Mas ressalva:

A transformação de um modo de ser de classe em modo de ser nacional é a operação de base da ideologia. Com a particularidade, no caso, de que não se trata de generalizar a ideologia da classe dominante, como é hábito, mas a de uma classe oprimida. Com efeito, Antonio Candido identifica a dialética de ordem e desordem como um modo de ser popular. Mais adiante ele a generaliza para o país, sublinha os inconvenientes de racismo e fanatismo religioso que ela nos poupou, e especula sobre as suas afinidades com uma ordem mundial mais favorável, que pelo contexto seria pós-burguesa. Assim, a matriz de alguns dos melhores aspectos da sociedade brasileira estaria na sociabilidade desenvolvida pelos homens pobres, à qual o futuro talvez reserve uma oportunidade. (SCHWARZ, 1987, p. 150-151). 


\section{Método integrativo}

Fluência e precisão caracterizaram o estilo crítico e teórico de Antonio Candido, perfeitamente avesso à pompa erudita e à pedantice. O diálogo amplo com as teorias e a lida penetrante e abrangente com uma bibliografia exaustiva não fez dele um citador exibicionista. Seu espírito independente não se prendeu a partidarismos devocionais de linhas teóricas, mantendo como lastro permanente de sua atividade intelectual e política uma coerência plena de senso comum, filtro para um aproveitamento equilibrado das tentativas de verdade e desvelamento do humano como medida de todas as coisas. Vem daí a metodologia dialética que ele chamou de "integrativa":

\footnotetext{
Quanto a ser ou não canônico sob o aspecto acadêmico, foi coisa que a partir de certa altura passei a não levar em conta. [...]

Creio que posso caracterizar minha carreira como um afastamento cada vez maior do "específico" em busca de um modo aberto e interativo, que passa por cima das divisões acadêmicas para chegar a um ponto de vista coerente. [...] a sociologia acadêmica e o marxismo acentuaram a tendência para estudar os aspectos sociais e ideológicos da literatura, e eu me pus a fazer aquelas misturas que constituem o meu modo de tentar a maior amplitude possível e evitar os dogmatismos, sem perder o prumo. Este prumo eu encontrei sobretudo na noção de estrutura, ligada às de processo e de montagem, como termos de uma visão integrada. Mas acima das posições teóricas, me parecem fundamentais a confiança na intuição e o desejo de correlacionar. Para uso próprio chamo a minha posição crítica de "integrativa", procurando fundir perspectivas diferentes para obter um resultado mais completo. E sempre tive o gosto de pensar em função dos contrários. (CANDIDO, 1993).
}

Como argumenta Roberto Schwarz, a atividade do mestre não se reduz à produção teórica no vazio, de modo que a perquirição do que viriam a ser os principais conceitos de sua obra revela-se uma falsa questão sendo dirigida a quem "nunca foi fanático de conceitos, nem aliás de métodos":

\footnotetext{
No seu trabalho a acuidade estética e a reflexão histórica pesam mais que a teoria abstrata, a qual qualificam segundo a circunstância. Sem prejuízo da bibliografia atualizada, a relação independente com as inovações conceituais de Europa e América do Norte é um dos segredos da sua inteligência crítica. Contrariando os nossos hábitos novidadeiros, ele as submete à verificação da experiência cultural acumulada no país, que não é posta de lado, ou melhor, que é valorizada como um fator de conhecimento. (SCHWARZ, 2009).
}

A presença discreta e alusiva, sem servilismo, dos aproveitamentos bibliográficos, com os quais mantém uma relação de assimilação sob debate subjacente, atiça a atenção dos leitores de Antonio Candido. Assim, por exemplo, podemos procurar sua relação implícita com o Deleuze de Proust e os signos (1987), sob hipótese de uma discussão ter sido estabelecida no ensaio curto da magnitude de "Realidade e realismo (via Marcel Proust)" (CANDIDO, 1993, p. 123). Neste, ao formular a noção de "transrealismo", o crítico ilumina, explicitamente no texto, Proust com Auerbach - e vice-versa - ao mesmo tempo em que poderia estar remetendo o resultado como exegese às categorizações do filósofo francês complicado.

Ao atribuir a Proust a superação de um realismo de superfície do tipo dos irmãos Goncourt, a qual seria o modo efetivo de uma apreensão do real pela sua essência no correr do tempo, Candido equaciona os termos e a correlação entre "estrutura" e "processo" para explicar as teorizações do próprio Proust em sua "redescoberta" do tempo e frisar seu desprezo pelos detalhes. O próprio escritor francês professa, desolado pela percepção equivocada que 
comumente lhe atribuía a qualificação de minucioso, que o que ele busca no movimento do tempo, pelo contrário, é extrair da dinâmica de seu "processo", através das similaridades, a "estrutura", para chegar à "lei" que dê acesso ao sentido essencial da existência. Como esclarece Candido, os detalhes só interessam na medida em que propiciam as afinidades entre eles, para que as analogias operadas pelas metáforas, por meio da síntese de uma "visão integrativa", unifiquem os pormenores - pormenores cuja "ligação em nível fundo configura o significado real - rede oculta [grifo nosso] inacessível à topografia realista positiva, como é a de Goncourt”:

\begin{abstract}
Há, portanto, vinculações ocultas que ligam os pormenores e compõem uma espécie de modelo permanente no meio da fuga do tempo. Elas seriam a base do projeto de Proust, ao provarem que é possível a luta da arte contra a dissolução operada por ele. $\mathrm{O}$ escritor procura recuperar a poeira das recordações porque a memória, permitindo remontar ao passado, mostra, meio contraditoriamente, que o que passa só ganha significado ao desvendar o que permanece; e este permite refluir sobre o pormenor transitório, o particular relativo, para compreendê-los. As vinculações fazem aparecer o desenho do modelo, como os números ligados pela ponta do lápis vão delineando uma figura nos livros infantis. (CANDIDO, 1993, p. 128).
\end{abstract}

Assim, afora o que por si já vale como exegese oferecida pelo "proustiano" brasileiro, a precisa concisão do curto recorte (1993) dá a sensação de que apresenta em acréscimo, didaticamente generoso, o acesso à complexidade conceitual elaborada minuciosamente por Deleuze em sua articulada obra sobre Proust. Ao comentar o que há de impressionante na atitude de Proust quando este, em radical oposição ao método Goncourt, apresenta insistentemente seu narrador como "incapaz de ver, de perceber, de lembrar-se, de compreender", Deleuze elabora seu diagnóstico. Podemos então constatar, através de suas correlações, que a leitura anterior facilita o entendimento desta:

O narrador é, na realidade, um enorme corpo sem órgãos. Mas o que é um corpo sem órgãos? Também a aranha nada vê, nada percebe, de nada se lembra. Acontece que em uma das extremidades de sua teia ela registra a mais leve vibração que se propaga até seu corpo em ondas de grande intensidade e que a faz, de um salto, atingir o lugar exato. Sem olhos, sem nariz, sem boca, a aranha responde unicamente aos signos e é atingida pelo menor signo que atravessa seu corpo como uma onda e a faz pular sobre a presa. A Recherche não foi construída como uma catedral nem como um vestido, mas como uma teia. O narrador-aranha, cuja teia é a Recherche que se faz, que se tece com cada fio movimentado por este ou aquele signo: a teia e a aranha, a teia e o corpo são uma mesma máquina. (DELEUZE, 1987, p. 182).

Por outro lado, o resultado, segundo Schwarz (2009), do modo de trabalho intelectual de Antonio Candido, que "foge à rigidez" no que diz respeito aos "conceitos que ele próprio cunhou", evidencia que o mestre substitui a discussão teórica isolada por uma "interpretação em funcionamento", como no caso da importante ideia de redução estrutural sobre a dinâmica nunca automática entre forma literária e processo social. Ao leitor ingênuo, a quem tal processo sugerir, por exemplo, influência da conceituação de "homologias estruturais" de Lucien Goldmann (1976), Schwarz responde:

O esforço de ligar a ordenação do mundo estético às ordenações históricas reais é a própria base da crítica materialista com viés estrutural. Ele está em Marx, Lukács, nos frankfurtianos, como aliás em Antonio Candido e, através dele, no trabalho de vários críticos brasileiros das gerações seguintes. Talvez se possa dizer que Goldmann, competindo no ambiente do estruturalismo francês, que era anti-histórico, tenha tentado fazer melhor, com os instrumentos marxistas, que são históricos, o que os estruturalistas faziam à maneira deles. 
E quanto à semelhança com "Dialética da malandragem":

De fato, há um paralelo. Também o Antonio Candido - que é da mesma geração do Goldmann - desenvolveu um tipo de estruturalismo histórico para responder pela esquerda ao estruturalismo anti-histórico que se havia formado nas ciências sociais e na crítica literária. Imagino que a semelhança se deva a esse contexto teórico-político em comum, e não à influência. Não custa lembrar que o melhor do pensamento crítico da esquerda brasileira depende de alguma forma de estruturalismo histórico. Basta pensar em Caio Prado Jr. e Celso Furtado. (SCHWARZ, 2000, p. 62).

\section{Grouchismo}

Alfredo Bosi encontra no ensaio "L' umorismo", de Pirandello, a concepção de humor como "sentimento do contrário" (BOSI, 1988, p. 189), cujo objetivo seria colher, por trás da mera comicidade, a "secreta amargura" do contraste entre o que "parece ser" e o que "deve ser" - o que, segundo o crítico, seria um anúncio precedendo a obra do dramaturgo italiano à maneira de um "prefácio cronológico e ideológico". De acordo com Bosi, Pirandello percebe que só uma "viva adesão afetiva e intelectual à matéria humana" constituiria o verdadeiro humor. O equívoco de atribuir-se indiscriminadamente a tantos escritores o qualificativo de humoristas, explica-se pela confusão desse "poderoso fruto de uma grande concentração de alma com as formas brilhantes da ironia, sorriso zombeteiro dos que se restringem a dizer o inverso do que pensam, sem aderir emocionalmente nem ao que dizem, nem ao que pensam” (BOSI, 1988, p. 189).

Embora o humor de Antonio Candido não deixe transparecer a "secreta amargura", certamente amenizada pelo espírito compreensivo e generoso, o tom de auditório de seus escritos, mais que letivo, parece o da sala de estar da fraternidade entre os humanos, de cuja ambientação risonha e ingênua podemos aproximar o humor cordial de Manuel Bandeira, como também caracterizar o crítico e o poeta com os versos do próprio Bandeira, em Estrela da tarde, sobre as "fantasias verbais" de Jaime Ovalle:

Que faziam rir os teus amigos e

Punham bondade no coração dos maus.

(BANDEIRA, 1974, p. 233).

Sendo tanto um como outro provas de que o humor, como atributo tão destacado em sua exclusividade humana, tem a voltagem alcançada em relação diretamente proporcional à grandeza dos sujeitos, em Antonio Candido ele é tão decoroso quanto constante nos extravasamentos discretos. Presente em qualquer página do autor como uma atmosfera permanente e silenciosa do estilo, há momentos, entretanto, em que sua explosividade parece desafogar gargalhadas no auditório da fraternidade.

No manifesto "O grouchismo", esse humor aparece como que teorizado na prática, dentro daquele sentido acima mencionado por Roberto Schwarz quando fala da "interpretação em funcionamento" em oposição à produção teórica no vazio. Publicado em agosto de 1941 nas primícias de sua atividade intelectual e política, na revista Clima, criada por Candido e outros chatos-boys (como Oswald de Andrade os chamava), este anti-stalinista de primeira hora, aos 23 anos de idade, brincava com as aporias do engajamento, já de saída com a alusão ao marxismo ${ }^{7}$ que obrigatoriamente se impõe com o homônimo do cômico norte-americano Groucho Marx.

O jovem Antonio Candido inicia o manifesto observando que no "nosso tempo", cheio de novos credos, o grouchismo conquista cada vez mais adeptos graças à sua decisiva tendência à

\footnotetext{
${ }^{7}$ Ver a respeito, adiante, na epígrafe do ensaio de Francisco Mariutti, "Notas para um verbete do Vocabulário Antonio Candido", o trecho do poema de Mário de Andrade, em Lira paulistana, aludindo a Antonio Candido com um trocadilho ortográfico: "bem marxante".
} 
ação, contrapondo-se, como Fausto, à prioridade do verbo professada pelo Evangelho de São João, e propondo uma nova moral baseada em dois princípios fundamentais: "otimismo criador" e "rejeição em bloco do convencional". Avesso à "justificação doutrinária - retórica, maçante e ineficiente", Groucho compreendeu que não se deve destruir para construir em seguida:

\begin{abstract}
Quando o tabu é derrubado, já deve estar nascendo de suas cinzas o novo tabuzinho, pronto e reluzente. É esta a sua profunda originalidade e a sua profunda divergência com os outros heróis deste século. Wladimir Ilitch, por exemplo, é o destruidor que espera tudo ruir para experimentar uma nova solução. O professor Freud é mais grouchiano, pois propõe ao mesmo tempo que depõe; mas é um grouchismo interior, com repercussões lentas e incertas na conduta imediata. Além disto, usa a análise, o que é um princípio antigrouchiano por excelência. (CANDIDO, 2009).
\end{abstract}

E a seguir o militante encaminha diretamente às fontes - como a cena engraçadíssima de Uma noite na ópera - o leitor que porventura ainda não teve contato com algum "evangelista do grouchismo".

Décadas depois, Décio de Almeida Prado, em homenagem ao velho amigo de Clima, ao falar do manifesto grouchista da juventude, denunciou a permanência no homem maduro dos talentos humorísticos, como numa carta em que Candido, ao remeter ao colega uma biografia de Rodolfo Valentino, parodiou o ator, fingindo ser a remessa um presente direto da fonte, numa hilariante encenação cheia de alusões e citações, de que o trecho inicial a seguir poderá dar amostra:

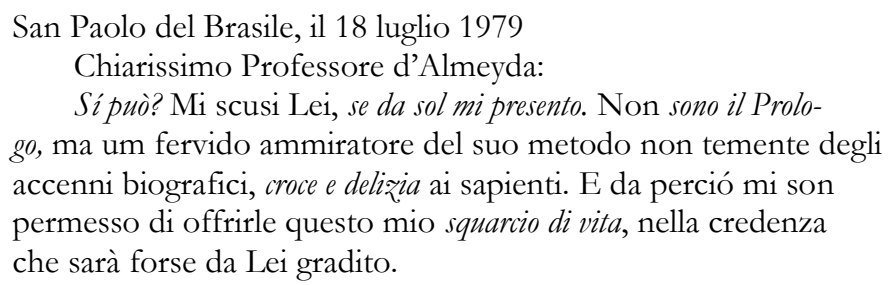

(PRADO, 1997, p. 172).

Décio de Almeida Prado explica, em "Antonio Candido e a 'pena da galhofa", as razões de ter escolhido essa via temática para a homenagem ao amigo, pois, certo de que os múltiplos aspectos de sua atuação intelectual e política seriam lembrados pelos outros colegas, optara (com conhecimento de causa de muitas décadas) por esse seu lado lúdico,

paródico, fantasioso, de admirador do pince-sans-rire francês e do non-sense britânico [...] O Antonio Candido sobretudo da fala, da oralidade, do gracejo, das imitações (de pessoas, de estilos, de sotaques), o farsista capaz eventualmente de sair pelas ruas de Portugal torcendo o bigode e ostentando uma impecável prosódia lisboeta. (PRADO, 1997, p. 168).

Outra passagem impagável é a representação de Coelho Neto, apresentada por Antonio Candido quando procura exemplificar a relação entre literatura e realidade, refletindo sobre o regionalismo, seu alcance e seus limites. Como limitação, aponta a dualidade de registros entre linguagem culta do narrador e linguagem estropiada ao figurar o pitoresco no discurso direto, um "centauro estilístico" discutível, motivado por intenções ideológicas para marcar distância. Então, como numa vingança popular, Candido cita o trecho de Coelho Neto, em que o personagem rústico figura confinado num "ridículo patuá pseudo-realista, no nível infra-humano dos objetos pitorescos":

- Não vou? Ocê sabi? Pois mió. Dá cá mais uma derrubada aí modi u friu, genti. 
Um dos vaqueiros passou-lhe o copo e Mandovi bebeu com gosto, esticando a língua para lamber os bigodes.

e transforma a parte do narrador, que vinha em registro erudito, num divertido carioquês:

Com efeito, supondo no narrador Coelho Neto uma performance fônica do tipo da que é corrente entre as pessoas cultas do Rio de Janeiro e nas cidades do Litoral Norte do País, o lógico seria (levando o critério adotado até às últimas consequências), que a escrita se apresentasse assim:

- Não vô? ocê sabi? pois mió. Dá cá mai zuma dirrubada aí módiu friu, genti. Unduch vaqueiruch passôlhocópo i Mandovi bebeu com gôchto, chticando a língua pra lambê ruch bigodich. (CANDIDO, 2002, p. 88-89).

Depois, numa de suas últimas entrevistas, cansado de bater na mesma tecla durante mais de setenta anos, como que exaurido pelas tentativas de explicação do óbvio, resume a questão da "redução estrutural" com uma espécie de ensaio relâmpago de radical didatismo, que poderia ter como título o "croquete" e a "vaca":

A minha fórmula é a seguinte: estou interessado em saber como o externo se transformou em interno, como aquilo que é carne de vaca vira croquete. O croquete não é vaca, mas sem a vaca o croquete não existe. Mas o croquete não tem nada a ver com a vaca, só a carne. Mas o externo se transformou em algo que é interno. Aí tenho que estudar o croquete, dizer de onde ele veio. (CANDIDO, 2011).

\section{O deserto dos tártaros}

Il Deserto dei Tartari (1940), de Dino Buzzati, conta a história de um jovem oficial, Giovanni Drogo, destacado ao sair da Escola Militar para a Fortaleza Bastiani, situada na fronteira com um reino setentrional. Para além dela se estende uma planície imensa, o Deserto dos Tártaros, de onde desde séculos não vem sinal devida. De tal modo que a guarnição parece inútil, pela ausência de inimigos visiveis ou mesmo prováveis. Mas há a ilusão de um perigo virtual e constante, que poderia causar a guerra e dar aos oficiais e soldados a oportunidade de mostrarem o seu valor. Por isso vivem todos numa expectativa permanente, que ao mesmo tempo é esperança -, a esperança de poder um dia justificar a vida e ter a oportunidade de brilhar.

Antonio Candido, O discurso e a cidade. ${ }^{8}$

Antonio Candido morreu a 12 de maio de 2017, quando o Brasil acabava de sofrer outro golpe ditatorial, golpe agora mais maquiado e mais kafkiano que o de 1964. Depois de quase quinze anos de esperança e emancipação popular, o capitalismo internacional atualizou estratégias para a sabotagem das assustadoras conquistas latino-americanas, com as novidades da assepsia virtual para não se sujar no banho de sangue costumeiro, com o adestramento de agentes em centros de treinamento no exterior, com o pool midiático, com a mobilização do mais boçal analfabetismo político - para garantir a corrupção legalizada, legítima e sacramentada da maisvalia, da miséria e da segregação dos desvalidos, em nome do combate à corrupção, palavra de

8 Trata-se do primeiro parágrafo do ensaio “Terceira [espera]: Na Fortaleza”, publicado na coletânea acima citada. Em depoimento à Folha de São Paulo, Antonio Candido revelou seu apreço à obra: o livro a que voltava "todos os anos" era $O$ deserto dos tártaros, que fala de uma angustiante expectativa. Disponível em: < www1.folha.uol.com.br /ilustrada/2017/05/1883486-candido-cunhou-interpretacoes-literarias-incontornaveis-leia-trechos.shtml >. Acesso em: 15 maio 2017. 
ordem predileta da corrupção fascista. Eram receitas de 1964, recicladas para os tempos ágeis e pasteurizados. Antonio Candido, com sua lucidez permanente, observou esse mundo estranho e deixou alguns comentários finais". Ainda que confessasse, já em 2014: "não me sinto mais parte desse mundo", quando provocado pelo surrado clichê da lavagem cerebral midiática, respondia firme ao jornalista:

Perguntei como ele, que havia sido um dos fundadores do PT, sentado ao lado de Sergio Buarque de Holanda na assembleia de fevereiro de 1980, via as concessões ideológicas do partido desde quando assumira o poder. "Continuo petista ainda assim", respondeu, "e gosto de dona Dilma, uma mulher forte".

No seu velório, a filha, Marina de Mello e Sousa, comentou:

Ele dizia que havia sido expulso do mundo.

Meu pai estava triste, muito surpreso com a direção que o mundo estava tomando. Ele era uma pessoa extremamente discreta. Representa um mundo de crença na igualdade que não aconteceu.

Dos que sobraram, nosso pequeno grupo periférico forçou seus limites para apresentar uma singela homenagem, como crianças que capricham na lição de casa. O resultado foi uma rica variedade de enfoques que, imaginamos com pouca modéstia, poderia surpreender o mestre generoso.

Assim temos, funcionando como uma ampla sondagem do lugar de Antonio Candido na cultura brasileira, os trabalhos de Francisco Mariutti e de Candice Carvalho. O primeiro, voltado para projeto maior, um Vocabulário $A C$, propõe antecipadamente sua contribuição desdobrando o conceito de forma literária, cujo significado teórico revela uma irradiação de tal plenitude que atinge todo o trabalho e a trajetória intelectual de seu sujeito. A segunda, seguindo trilha semelhante, aprofunda as correlações e fases do autor, percorrendo com minúcia a teia bibliográfica de sua fortuna crítica para, fechando o foco na obra de Guimarães Rosa, comprovar a fluência e a harmonia entre o que o crítico anunciou como processo formativo e o grande resultado literário brasileiro que a obra do escritor mineiro significou.

A intensidade e variedade dos estudos que a obra de Antonio Candido ofereceu provocam a situação impraticável de esgotar seus temas. Nem por isso nossas amostras, focadas no particular, deixaram de exemplificar aquela riqueza. Da literatura brasileira à literatura mundial, do poeta local ao escritor da marginalidade, da prosa à crônica e da ficção ao memorialismo, dos conceitos a discutir aos direitos a preservar, do interno ao externo no concerto mundial, o leitor poderá comprovar a ampla discussão da obra, que essa coletânea realizou.

Assim, descobriremos, especialmente inter-relacionada, a sensibilidade perspicaz de um Antonio Candido leitor de Fausto, por meio da investigação de Marcus Vinicius Mazzari, germanista e tradutor responsável pela mais atualizada e precisa edição brasileira da obra de Goethe - munido, portanto, de ferramentas refinadas para extrair da leitura do mestre toda a riqueza de suas correlações.

Ainda no plano da literatura mundial, Mona Lisa Bezerra Teixeira se detém sobre o importante ensaio "Da vingança" para colocar em discussão a percepção de que a vingança do Conde de Monte Cristo seja mero produto do individualismo burguês, contrapondo a esse limite a ideia de justiça e a força revolucionária da lenda que se espande pela oralidade.

\footnotetext{
9 Disponíveis em: < www1.folha.uol.com.br/ilustrada/2017/05/1883652-nao-me-sinto-mais-parte-desse-mundodisse-candido-em-2014.shtml>, < www1.folha.uol.com.br/ilustrada/2017/05/1883498-velorio-de-antonio-candidotem-presenca-de-lula-e-outros-politicos.shtml >. Acesso em 12 maio 2017.
} 
A aguda capacidade instrumental da obra didática, prova da essencial vocação para o magistério no autor de $N a$ sala de aula e $O$ estudo analítico do poema, permite a Derivaldo dos Santos e Gabriella Kelmer, no momento de avaliar o rico resultado poético de uma produção da literatura potiguar, tecer e estender seus conceitos teóricos mais universais ao jogo dialético com o local, jogo e conceitos fundamentais para o autor de Formação da literatura brasileira.

O estudioso verdadeiramente democrático, socialista, devotado à divulgação da importância de Adoniran Barbosa na música popular brasileira é o mesmo que se mostra atento à obra de João Antônio, como prova o estudo que, já pelo título, "Na noite enxovalhada", revela a força expressiva de sua análise e interpretação. É o que evidencia Manoel Freire ao abordar o escritor dos pobres-diabos, revelando a operacionalidade fluente e transtemporal do ensaio "Dialética da malandragem", que ultrapassa os limites do "tempo do Rei" para iluminar os marginais das grandes cidades brasileiras do século XX.

Tanto quanto atento a uma literatura convergente ao marginal, Antonio Candido mostrou-se um teórico principal do gênero crônica, tão bem qualificado por ele como literatura da "vida ao rés do chão". Seu vínculo com Rubem Braga fica assim consagrado, o que permite à pesquisadora Lourdes Patrini dispor de seu quase infinito arquivo de publicações do cronista, para, em parceria com Mácio Alves de Medeiros, sondar na imensidade emaranhada desse universo diário os veios preciosos dessa relação.

Do mesmo modo, o memorialismo brasileiro, a que se dedica Afonso Henrique Fávero como projeto de estudo de longa duração, mostra-se contemplado pela vertiginosa capacidade de observação da forma literária que nosso Mestre Açu-Acê dedica a todas as suas manifestações. É o que permite ao estudo específico, que Fávero empreende, passar do romance, cuja condição formativa no Brasil fez dele "verdadeira forma de pesquisa e descoberta do país", para a rica miríade de registros que o pesquisador encontra no longo caminho do memorialismo brasileiro.

Como vimos, acima, no depoimento de Roberto Schwarz, Antonio Candido sempre se mostrou avesso à rigidez dos conceitos, mesmo quando cunhados por ele próprio. Assim teremos, nessa flexibilidade, a condição propícia à discussão de seus pressupostos, necessidade de que Peterson Martins não foge ao colocar na pauta a importante percepção do superregionalismo, atribuído por Candido à obra de Guimarães Rosa - conceito posto como ponto de partida na elaboração do que o pesquisador propõe como hiper-regionalismo ao ampliar seu alcance tanto à proximidade de Ariano Suassuna quando à peculiaridade de José Saramago.

Finalmente, ainda dentro do aproveitamento de conceitos que a obra do mestre sugere, Rosanne Bezerra de Araújo e Jorge Witt demarcam um aspecto profundo e fundamental de suas raízes, seiva e folhagem, onipresentes na amplidão dos estudos maiores e menores de Candido como um nume tutelar: a relação entre o local e o universal, no jogo de influências, respostas e assimilações entre o fluxo interno e externo, que o embate da cultura brasileira provoca, na arena de "Oropa, França e Bahia".

E assim ficamos por aqui, agora sem ter para nos consolar uma dialética da malandragem atualizada, para o exercício dos novos tempos sombrios no deserto dos tártaros.

Brasil, maio de 2018.

\section{REFERÊNCIAS BIBLIOGRÁFICAS}

ALMEIDA, Manuel Antônio de. Memórias de um sargento de milícias. São Paulo: Ática, 1991.

BANDEIRA, Manuel. Estrela da vida inteira. 5. ed. Rio de Janeiro: José Olympio, 1974. 
BENJAMIN, Walter. O narrador. Considerações sobre a obra de Nikolai Leskov. In: Magia e técnica, arte e politica. Tradução de Sergio Paulo Rouanet. São Paulo: Brasiliense, 1985. (Obras escolhidas, 1). p. 197-221.

BOSI, Alfredo. Um conceito de humorismo. In: ideológica. São Paulo: Ática, 1988. p. 188-191. Céu, inferno. Ensaios de crítica literária e

CANDIDO, Antonio. A literatura e a formação do homem. In: Textos de intervenção. Seleção, apresentação e notas de Vinicius Dantas. São Paulo: Duas Cidades; Ed. 34, 2002, p. 77 92.

Dialética da malandragem. Revista do Instituto de Estudos Brasileiros, n. 8, p. 67-89. São Paulo: Universidade de São Paulo, 1970.

Entrevista a Gilberto Velho e Yonne Leite (Museu Nacional, UFRJ). Edição de texto de Dora Rocha. Colaboração Eunice Personini. Publicada em junho de 1993. Canal Ciência. Portal de Divulgação Científica e Tecnológica. Instituto Brasileiro de Informação em Ciência e Tecnologia (IBICT). Disponível em: < canalciencia.ibict.br/notaveis/ livros/antonio_candido_14.html >. Acesso em: 06 jan. 2016.

. Formação da literatura brasileira: momentos decisivos. 4. ed. São Paulo: Martins, 1971. 2v.

. O discurso e a cidade. São Paulo: Duas Cidades, 1998.

. O grouchismo. Manifesto. Revista Serrote, n. 2, São Paulo, julho 2009. Disponível em: < revistaserrote.com.br/2011/06/o-grouchismo/ >. Acesso em: 23 mar. 2017.

O socialismo é uma doutrina triunfante. Entrevista a Joana Tavares. Brasil de Fato, 8 de agosto de 2011. Disponível em: < brasildefato.com.br/node/6819/ >. Acesso em: 03 abr. 2017. Letras, 1993.

Realidade e realismo (via Marcel Proust). In: Recortes. São Paulo: Companhia das

ESCOREL, Ana Luisa. Antonio Candido e a menina. Revista Piaú, n. 20, Rio de Janeiro, maio 2008. Disponível em: < piaui.folha.uol.com.br/materia/antoniocandidoeamenina/ > Acesso em: 12 maio 2017.

O pai, a mãe e a filha. Rio de Janeiro: Ouro sobre Azul, 2010.

GOLDMANN, Lucien. Sociologia do romance. 2. ed. Tradução de Álvaro Cabral. Rio de Janeiro: Paz e Terra, 1976.

HOLANDA, Sérgio Buarque de. Raízes do Brasil. Edição crítica. Organização de Lilia Moritz Schwarcz e Pedro Meira Monteiro. Estabelecimento de texto e notas de Marcelo Diego e Mauricio Acuña. São Paulo: Companhia das Letras, 2016.

LUKÁCS, Georg. A teoria do romance. Um ensaio histórico-filosófico sobre as formas da grande épica. Trad., posfácio e notas de José Marcos Mariani de Macedo. São Paulo: Duas Cidades; Ed. 34, 2000. 
PRADO, Décio de Almeida. Antonio Candido e a "pena da galhofa". In: lugares. Do teatro ao futebol. São Paulo: Companhia das Letras, 1997. Seres, coisas,

RAMOS, Graciliano. Infância. 20. ed. Rio de Janeiro: Record, 1984.

SCHWARZ, Roberto. Entrevista. Revista Literatura e Sociedade, n. 11, 2009. Disponível em: < revistas.usp.br/ls/article/view/24695 >. Acesso em: 27 abr. 2017.

O pai de familia e outros estudos. Rio de Janeiro: Paz e Terra, 1978.

Pressupostos, salvo engano, de 'Dialética da Malandragem'. In: Que horas são? São Paulo: Companhia das Letras, 1987.

- Tira-dúvidas com Roberto Schwarz. Entrevista a Afonso Fávero, Airton Paschoa, Francisco Mariutti, Marcos Falleiros. Novos estudos Cebrap, n. 58. São Paulo, novembro de 2000. p. 53-71.

Um mestre na periferia do capitalismo/Machado de Assis. São Paulo: Duas Cidades, 1990.

VERGUEIRO, Maria Clara. 'O mundo de meu avô era o meu preferido', rememora neta de Antonio Candido. Folha de São Paulo, 20 maio 2017. Disponível em: < www1.folha.uol.com.br/ilustrada/2017/05/1885549-o-mundo-do-meu-avo-era-o-meupreferido-rememora-neta-de-candido.shtml >. Acesso em: 03 mar. 2018.

VILAÇA, Marcos Vinicios Rodrigues. Discurso de recepção à posse de Ariano Suassuna. Academia Brasileira de Letras, 09 de agosto de 1990. Disponível em: < academia.org.br/academicos/ariano-suassuna/discurso-de-recepcao >. Acesso em: 06 jan 2013. 